OKSANA KAMINSKA,

\title{
PARTICIPATION OF SIDOR HOLUBOVYCH IN SOCIO-POLITICAL PROCESSES IN THE GALICIAN LANDS DURING THE WORLD WAR I
}

The civic-political activity of Sydor Golubovych during the World War I was analyzed in the article based on the complex study of archive sources, periodicals and scientific literature. His role in the political organizations in Vienna during his emigration period in 1914-1915-s and after his return to L'viv in 1915-1918-s was determined. Namely, the prerequisites of reorganization of the Main Ukrainian Council into the Common Ukrainian Council, problem of political struggle among different party groups within the political circles in Galicia and Bukovina were highlighted. The main aspects of Golubovych's activity in the Common Ukrainian Council (CUC) were revealed, within the council his main attention was drawn to the issues of the "Military bank" creation, issues related to the Ukrainian refugees, migrant workers, internees from Galicia and Bukovina, who according to the official data were $\mathbf{9 0}$ thou in different parts of Austria, Germany and Czech Republic. Moreover, it is mentioned that S. Golubovych was a participant of the political actions for autonomy of Ukrainian schooling, separate Ukrainian university opening in L'viv, transformation of the STC into the Ukrainian academy of science, etc.

It was found that after his return to L'viv in August 1915, S. Golubovych as a member of the L'viv's delegation of the CUC and member of the Regional Credit Union (RCU) was predominantly responsible for the problems of region's restoration after the military actions. Simultaneously, the main attention was drawn to the busy social activity, namely he was included into the senior council at Stavropigijskyi institute - former Moscow-oriented institution transferred to the Ukrainians by the Austrian governor general Kollard, and was a founder and editor of the newspaper "Ukrayins'ke slovo" that was the main media source in Galicia. Furthermore, during 1917-1918-s the politician frequently visited Ternopol's region where he endeavored to keep close contacts with his electorate.

A role of S. Golubovych was described before the November events of 1918, where he as a figure of the Ukrainian National Democratic Party (UNDP) and member of the Ukrainian Parliamentary Representation (UPR) participated in meetings and demonstrations' organization devoted to the independence proclamation of the Ukrainian National Republic (UNR), peace treaty agreement in Brest-Lytovsk, was actively involved in implementation of so called "viche week" organized to support the autonomy demands of the Eastern Galicia as a separate Ukrainian territory within the Austrian monarchy, etc.

Key words: S. Golubovych, the Ukrainian Parliamentary Club, Ukrainian National Demicratic Party (left-wing opposition), Common Ukrainian Council, Ukrainian Parliamentary Representation, newspaper "Ukrayins'ke slovo".

Relevance of the issue

Expanding of prosopographical studies is crucial for contemporary historical science. Particularly, the historians have drawn attention to the heritage study of those socio-political or cultural figures who made a significant contribution into development of national movement, statehood, established a base of further development of contemporary Ukrainian political culture, etc. Reproduction of their activity connected with social conditions of the time, utility of their nation-based experience is rather urgent nowadays and has a special meaning for developing state-related space of contemporary Ukraine. The special interest is devoted to the figures that are completely unexplored nowadays. Sydir Tymofijovych Golubovych (1873-1938) occupies an important place among many "forgotten" public and political figures of Galicia at the end of the $19^{\text {th }}$ - the first quarter of the $20^{\text {th }}$ century. He had authority over cultural and educational, cooperative, economic and political regional communities, he actively protected the interests of Ukrainian population in the Austrian parliament and Sejm of Galicia as a depute, played a special role in development of the West Ukrainian National Republic, having led administration during the most crucial period of statehood. The important aspect of his multifaceted activity is his participation into political support of the Ukrainians from Galicia during the World War I, namely in the Common Ukrainian Council (CUC), Ukrainian Parliamentary Representation (UPR), Regional Credit Union (RCU), newspaper's editorial office "Ukrayins'ke slovo (Ukrainian Word)", etc. 
The issue of S. Golubovych's activity during the World War I is practically unexamined in the Ukrainian historiography. Only particular fragments of his political and parliamentary activity can be found in the studies of V. Rasevych, M. Kuhutiak (2008), P. Hutsal (1998), I. Pater (2000a), P. Lepisevych (2005), I. Vasylyk, O. Pavlyschyn (1999), who partially mentioned the figure under the context of their interests. Namely, in the studies of V. Rasevych (1999) and I. Pater (2000b) devoted to the activity of the Ukrainian political organizations in Vienna during the World War I, S. Golubovych is mentioned as a representative of the left-wing opposition group of the UNDP that was established as opposed to the party leadership represented by K. Levytskyy, M. Vasyl'ko and E. Olesnytskyi, some connections of the opposition figures with the Union for the Liberation of Ukraine were followed as well as their work regarding prisoners of war, refugees, migrant Ukrainian workers, issues regarding ruined Galicia due to military actions. Some references to Golubovych's activity in the Common Ukrainian Council can be found in the works of P. Lepisevych (2005) and M. Kuhutyak (2008). Some records from Golubovych's public and political work after his returning to Lviv in 1915 are in the articles of O. Kyrychuk and P. Hutsal (1999), where his work for Ukrainian-oriented management of Stavropigijskyi institute, direction of the Regional Credit Union, newspaper's editorial office "Ukrayins'ke slovo", etc. are mentioned. The materials from the funds of the Central State Historical Archives of Ukraine in L'viv (funds 682, 359, 440, 129), Central State Archives of Supreme Bodies of Power and Government of Ukraine (fund 3807) and periodicals of that time (newspapers "Ukrayins'ke slovo" (Ukrainian Word) issued during 1916-1917-s and "Svoboda (Freedom)" issued in 1918) formed the resource base of the article.

The purpose of article is to analyze political and public work of S. Golubovych during the World War I and demonstrate his impact on the CUC (in 1915-1916-s) and UPR (in 1916-1918-s) that were the major political institutions of the Ukrainians within Austria-Hungary, as well as to determine the main directions of work of the mentioned organizations, and consider their achievements and drawbacks.

\section{Methods}

The principles of objectivity and historicism based on the complex usage of sources and scientific literature have composed the base of article. Historiographical analysis and synthesis were used for solution of research tasks as well as they were applied to systematization of historiographical heritage related to the public and political activity of S. Golubovych during the World War I though the light of historical processes and events that permitted to consider critically all existed works, compare previous results and explore the extent of theme's consideration. Moreover, the methods of systematization and classification were used. Their usage permitted to define and group source materials (funds of the CSHAUL f. 440, 359, 129, 682; CSASBPGU - f. 3807; materials of newspapers "Ukrayins'ke slovo (Ukrainian Word)" issued in November-December 1916 and August-November 1917; "Svoboda" - January-August 1918) related to some particular aspects of S. Golubovych's participation in the Common Ukrainian Council (1915-1916-s), Ukrainian Parliamentary Club (1914-1915-s), Ukrainian National
Democratic Party (1914-1918-s), Ukrainian Parliamentary Representation (1916-1918-s), etc. Empirical method facilitated to reconstruct the unknown facts from life and public-political activity of S. Golubovych, according to which it is possible to obtain informative data via analyzing the issues of that time. In particular, the speeches of S. Golubovych at meetings of the Broader National Committee of the UNDP, reports from the CUC, RCU, UPR were published in the newspapers "Ukrayins'ke slovo" and "Svoboda" that facilitated to make some generalizations regarding his public and political activity related to Galicia's reconstruction ruined by military actions, interests' protection of the internees, refugees, political actions for autonomy of Ukrainian schools, organization of mass council movement that should create prerequisites for Ukrainian national struggle, etc.

\section{Research and Results}

At the beginning of the World War I and Russian occupation, S. Golubovych immigrated to Vienna as many others political figures. The Austrian capital became a center of Ukrainian political life for almost two years. Founded in L'viv in August 1914, the inter-party organization - Main Ukrainian Council (MUN) that should represent the interests of Ukrainians in the Austrian government and coordinated activity of Ukrainian political organizations couldn't immediately renew its activity in immigration. The reason was that not all its members could simultaneously move to the city. Under those circumstances all power was concentrated in the hands of political triumvirate: K. Levytskyy, M. Vasyl'ko and E. Olesnytskyi. Having been pushed into the marginal category, other Ukrainian politicians "didn't want to be involved or went savage, and without any influence" gradually began to form an opposition group, the base of which became the Ukrainian Parliamentary Club (UPC) and left wing of the Ukrainian National Democratic Party (UNDP). S. Golubovych with E. Levytskyy, O. Koless, L. Tsegelskyy, L. Levytskyy, Y. Folys, V. Batchynskyy, P. Perfetskyy and other deputies belonged to that influential opposition formed by E. Petrushevych.

Being a member of the Ukrainian Parliamentary Club in Vienna, S. Golubovych repeatedly called for an association of all national-political forces that were in immigration into a common Ukrainian organization as a constant opposition between particular party groups in the politics of Galicia and Bukovina had reduced the significance of the Ukrainian issue as a crucial factor of European policy. Namely, the issue was raised at the meeting of the Ukrainian Parliamentary Club (UPC) on December $10^{\text {th }}, 1914$. However, K. Levytskyy, M. Vasyl'ko began a struggle with the opposition and confronted Council's restructuring. An endeavor to accept a statute of new common Ukrainian organization wasn't successful at the conference of parliamentary and sejm ambassadors of Galicia and Bukovina on December $15^{\text {th }}, 1914$. The issues regarding power of the delegates of the Union for the Liberation of Ukraine (ULU) and Bukovina, participation of church representatives and figures from the Christian-public movement as well as giving a right of veto for the parties provoked discussions while reorganized meetings of the Council (Lepisevych, 2005: 17).

At the beginning of 1915 the conflicts within the UNDP and UPC were known to public. Particularly, the main drawbacks of the Ukrainian policy, the main of which was considered "a lack of supreme national representation", 
were defined at the conference of the Ukrainian students in Vienna (Rasevych, 1999: 324). Such position of students, increasing influence of the Polish political forces as well as a threat of losing authority in Austrian and German governmental circles coerced the politicians from Galicia and Bukovina to reconcile and consider a common consensual platform. Eventually, K. Levytskyy, M. Vasyl'ko agreed to reorganize the CUP after four months of consolidated negotiations.

Consequently, on April $30^{\text {th }}, 1915$, the CUP was decided to be reorganized into the Common Ukrainian Council (CUC) at the meeting of Galicia's representatives, Bukovina's national democrats and the Union for the Liberation of Ukraine, a statute was signed, and the first meeting was convened on May $5^{\text {th }}$.

The CUC was proclaimed to be a representation of Ukrainian people during the war and till November 1916 it coordinated the work of all political representative offices of Ukraine that had an ultimate goal of state independence. The CUC included 34 delegates, among them were 14 delegates of the Ukrainian National Democratic Party (UNDP) from Galicia (10 representatives from the National Committee and 4 from the Ukrainian Parliamentary Club), 6 from the Ukrainian Radical Party (URP), 4 from the Ukrainian Social Democratic Party (USDP). Bukovyna was represented by 5 national democrats, 1 member of the Ukrainian national party and 1 social democrat; Naddniprianschyna - by 3 delegates of the ULU (Levytskyy, 1928: 153). The constant executive body of the CUC was the presidency consisted of the president K. Levytskyy and four vice-presidents, representatives of the UNDP, URP, USDP from Galicia and Bukovina (M. Vasyl'ko, E. Petrushevych, L. Batchynskyy and M. Hunkevych). The delegate of the union O. SkoropysJoltuchovskyy had a right to vote only during discussion of common Ukrainian issues.

New Council energetically started to work, established several sections, namely judicial-political (14 members), media (9 members), economic, cultural and emigrational ${ }^{1}$. The last three sections had 5 members in each who played a role of mediators between the CUC and other Ukrainian institutions with similar tasks. The Ukrainian Military Department was recognized as an autonomous body of the CUC and managerial body to the legion of the USS. Later the Ukrainian media bureau was created on the rights of independent body (Kuhutyak, 2008:106).

It should be mentioned that $\mathrm{S}$. Golubovych was an active participant of the CUC. He was involved in discussion of all urgent issues that were solved during the war period. Namely, on July $1^{\text {st }}, 1915$ at the Council's meeting, he participated in discussion of "Military bank" established by the Austrian government that year for renewal of ruined Galicia. The fact that Polish and Jews should be included into the management raised concerns, as the Polish could usurp power in the bank and use it for their national interests. "This could weaken our political position - S. Golubovych claimed during the discussion - as the Polish would draw our delegates into arguments and the delegates could distance from a commission [...] We should achieve special commissions where Ukrainians were predominantly presented" ${ }^{2}$. As a result a decision

\footnotetext{
${ }^{1}$ Central State Historical Archive of Ukraine in Lviv, Fund. 682. List. 1. File. 43, P. 4-5

${ }^{2}$ Central State Archive of the highest authorities and administration of Ukraine, Fund 3807, List 2, File 3, P. 80
}

was accepted, "the delegates of "Rural master" shouldn't be sent to the Regional commission of agricultural issues as well as to the Regional commission of cities and villages' reconstruction" 3 , in order to provide none reasons to think that Ukrainians could cooperate with Polish.

Moreover, except solving the issues of Ukrainian economic life and regional renewal, S. Golubovych had raised the issues of Ukrainian refugees and Ukrainian internees from Galicia and Bukovina at the meetings of the CUC who were in quantity more than 90 thousands in different areas of Austria and Czech Republic. The concentration camps for emigrants-refugees and the internees were created in Gmind, Wolfsberg, Kirchberg, Velvarm, Greding-Nideralm, Hocen, Moravska Trebova (Romanyuk, 1999: 279).

The situation with Ukrainian refugees had especially exacerbated in connection with new attacks of the Russian army in Galicia and Bukovina at the end of summer beginning of autumn 1916. The meetings of the CUC were devoted to those issues on August $26^{\text {th }}$ and September $2^{\text {nd }}$ 1916. Except S. Golubovych, L. Levytskyy, A. Zuk, Ya. Vesolovskyy, V. Temnytskyy and others also participated in discussions, where the main attention was drawn to a level of sanitary conditions of barracks' building, nutrition, spiritual needs of refugees (schools for children, extra curriculum courses for the youth and adults, libraries, books, newspapers, amateur performances, etc.), and other ways of material support ${ }^{4}$. The referents admitted that "barracks are building uninhabitable. Still nothing has been done even in those communities that were burn or destroyed by our army from strategic reasons..." Namely, S. Golubovych mentioned: "...one should have nerves of steel to see calmly the misfortune that has happened to our people connected with coercive evacuation [...] Moreover, the coercive evacuated people have borne great losses, having sold all their property for nothing" 6 . K. Levytskyy responded to the comments of $\mathrm{S}$. Golubovych that the issue of mass coercive evacuation was raised by the presidency in the presence of President of Ministers count Schtirk, he responded that evacuation would be suspended ${ }^{7}$. It was ratified to regulate internal life of the evacuated, involve other Ukrainian organizations who were interested in that activity, hire Ukrainians for the positions of administrative staff of the camps, initiate cooperative and handicrafts.

The Common Cultural Ukrainian Council (CCUC) was created as a part of the CUC (in the documents the Ukrainian Cultural Council or Cultural Council - O. K.) for cultural life of Ukrainian refugees; the organization was involved in the issues of functioning and financing of the Ukrainian cultural-educational associations, namely network organization of national schools and professional industrial-agricultural and economic courses. It consisted of representatives of all Ukrainian cultural, scientific and political associations, former Ukrainian ambassadors in the Galicia's sejm and Austrian parliament (Kulchytskyy, 2011: 133).

\footnotetext{
${ }^{3}$ Ibid, P. 81

${ }^{4}$ Central State Historical Archive of Ukraine in Lviv, Fund 359, List1, File, 370, P. 57-58

${ }^{5}$ Ukrayinske slovo, 1916, February $24^{\text {th }}: 1$.

${ }^{6}$ Central State Archive of the highest authorities and administration of Ukraine, Fund 3807, List 2, File 3, P. 294.

lbid, P. 297.
} 
Cooperating with the CCUC, the representatives of the CUC provided political actions for autonomy of Ukrainian schools, opening of Ukrainian university in L'viv, the STS conversion into the Ukrainian academy of science. "The existed school councils, - according to one of the administrators of the CUCC, O. Koless, - don't support Ukrainian schooling; they rather halt its development. Ukrainian schooling should become autonomous, and be subordinated only to the Central government, this will create a basis for successful development of Ukrainian schooling in the future" ${ }^{\prime 8}$. A crucial result of cooperation between the governmental-political section of the CUC and CUCC was a memorial production in the issue of Ukrainian schooling that was presented to the primeminister count Schtirk for his consideration ${ }^{9}$.

The politicians of the CUC began to promote official implementation of the nomenclature name "Ukraine", "Ukrainian" in order to prevent all attempts to equate the local population with Russians in the future. They had designed a memorandum for the Austrian government with a demand to name the Ukrainian people with the words "Ukrainian" instead of "Russian" (Kuhutyak, 2008: 107).

The CUC gave high priority to the demand of Galicia imperial land's division into the Ukrainian and Polish provinces as all Ukrainian national-political forces of Austria after $1848^{10}$. On August $11^{\text {th }}$ and October $25^{\text {th }}, 1915$ at the meetings where S. Golubovych was presented among others, the head K. Levytskyy informed that the primeminister Schtirk declared in private: “... the division of Galicia is a definitely decided issue at the highest political levels and is diplomatically arranged between Austria and Germany" (Kuhutyak, 2008: 107).

Nevertheless, according to the results of negotiations, it didn't manage to reach much. Due to the researchers $\mathrm{V}$. Kondratiuk and V. Regulskyy, "As before the war, Austria paid attention to the strong Polish national movement and "didn't want to tease Polish with the concessions to Ukrainians in Galicia and the Polish provinces of Russia" (quotation due to: Vasylyk, 2003: 70). Among the results of the CUC's management, only an appointment of Galicia's governor the German general Kollard instead of the Polish Korytovskyy could be mentioned, Kollard agreed to transfer Moscow-oriented institutions into the Ukrainian's possession, facilitated to secure the rights of Ukrainian language and acceptance of Ukrainians into the administrative positions. Furthermore, in August 1915, the legion of the USS was officially transformed into a regular part of the Austrian army; the Ukrainian schools began to open on the occupied territories of Cholmschyna and Volyn (Kuhutyak, 2008: 107).

Having admitted passiveness of K. Levytskyy and M. Vasyl'ko in maintenance of the Ukrainian policy, a part of the opposition from the Ukrainian Parliamentary Club left the CUC. E. Petruschevych and T. Vojnarovskyy were the first who left the Council, as well as L. Tsegelskyy who left his position of a secretary. The rest of the opposition, including S. Golubovych didn't leave the CUC, in order to prevent its self-destruction (Lepisevych, 2005: 19).

The opposition decided to establish its alternative structures. The main step in that direction was an attempt

\footnotetext{
${ }^{8}$ Ibid, P. 84.

9 lbid, P. 85.

${ }^{10}$ Central State Historical Archive of Ukraine in Lviv, Fund 440,
} List 1., File 12, P. 1.

ISSN 1728-9343 (Print)

ISSN 2411-3093 (Online) to establish own media bureau. In August 1915, having returned to L'viv with T. Vojnarovskyy, L. Tsegelskyy and other leaders, S. Golubovych became a founder of the daily newspaper "Ukrayins'ke slovo" that he had edited and issued for two years (Hlovatskyy, 2008: 211). The newspaper that was oppositional to the newspaper "Dilo" had become one of the most prominent issues in the Eastern Galicia for a short period of time. A lot of editorial materials-reviews were written by S. Golubovych himself that proved his journalism talent. Particularly, when revolution began in Russia S. Golubovych wrote in one of his editorial materials "Russian Revolution and Ukrainian Issue": "The world war in a companion with this revolution... should at least partially embody our dreams about Ukraine" ${ }^{11}$. If we take into consideration that the newspaper was under strict censorship, the author could express his though clearly and accurately for the readers (Hutsal, 1999: 54).

It should be mentioned that the journal "Ukrayins'ke slovo" was published in the publishing office of Stavropigijskyi institute in the life of which S. Golubovych was actively involved, being a member of the Senior Council of its "Ukrainian-oriented" staff during 1916-1918-s ${ }^{12}$. He occupied a position of syndic at Stavropigijskyi institute, his responsibilities included to solve the judicial issues of the university ${ }^{13}$. He managed to occupy a prominent position in the structure of the Ukrainian Greek Catholic Church, renew the work of publishing house and bursa on the Ukrainian platform under the tough war conditions during the period of his presence among "Ukrainian-oriented" staff at Stavropigijskyi institute (Kyrychuk, 2000: 337).

Meanwhile a political struggle continued in the political circles of Galicia-Bukovina, the next step of opposition was a demand to include changes into a structure of the CUC, namely creation of the L'viv's delegation of the CUC with the division into separate departments and establishment of the local Council's committees in the region. Such changes were grounded on the reason that creation of general network within all regional departments would provide better control of the political life in Galicia. Being afraid of seizure of power in the Council, K. Levytskyy insisted that the CUC should stay in Vienna. Eventually, the decision was accepted to leave the Council with the previous staff at the meeting of the CUC on May $19^{\text {th }}, 1916$, and in autumn 1916 the permanent delegation of the presented members of the CUC in L'viv was created "till the CUC and Presidium transfer their office from Vienna to L'viv"'14

On September $2^{\text {nd }}, 1916, S$. Golubovych attended a meeting of the CUC in Vienna for the last time, where he was included into the L'viv's delegation along with M. Gankevych, O. Nazarchuk, S. Baranov, V. Pajnek, V. Bachynskyy and T. Vojnarovskyy ${ }^{15}$. That political structure had its own office and created departments that were headed by one of the CUC's members. The delegation was ruled by the presidency that included a head and members of three political parties - national-democratic,

\footnotetext{
${ }^{11}$ Ukrayinske slovo, 1917, March $18^{\text {th }}: 1$

${ }^{12}$ Central State Historical Archive of Ukraine in Lviv, Fund 129, List 2. File 21, P.3.

${ }^{13}$ lbid, P. 2 (rev).

${ }^{14}$ Central State Archive of the highest authorities and administration of Ukraine, Fund 3807, List 2, File 3, P. 109.

${ }^{15}$ Ibid, P. 110
} 
radical and social-democratic (Pavlyshyn, 1999: 74). The separate local committees of the CUC planned to be established in provinces that would locally provide organizational-political activity within the CUC's statutes.

The L'viv's delegation of the CUC was planned to have the following departments: 1) political (would be engaged in all organizational-political activity); 2) economic (divided into two separate sub-departments - sections for cities and villages). It should provide economic renewal of the region in cooperation with "Rural master", the Regional Audit Union and Regional Credit Union; 3 ) cultural (controlled activity of all regional Ukrainian cultural-educational institutions); 4) school (involved in new trade and professional schools development for the disabled members of the USS, textbooks' publishing, etc.); 5) sanitary and 6) department for the occupied regions $^{16}$

Therefore, it was planned to begin active work in national-political, cultural-education and financial-economic spheres in the regions liberated from the Russian troops. However, the Ukrainian national-political movement met a new challenge. The change of geopolitical situation forced the Habsburg's monarchy to take a final decision of solving the Austro-Polish issue and having rejected the idea of Ukrainian imperial land. The manifests of the German Kaiser and Austrian Caesar from November $5^{\text {th }}$, 1916, regarding proclamation of the Polish Kingdom that was created on the Polish territories included to the Russian Empire and separation of Galicia, had vanished all hopes of the Ukrainians. In fact it meant enforcement of the Polish power on the whole Galicia's imperial territory without its division into the Ukrainian and Polish parts.

"The act of two Caesars" meant destruction of the proAustrian oriented CUC, its authority was undermined. M. Gruschevskyy mentioned in relation to those events that "a rescript regarding expansion of Galicia's autonomy sounded the death knell of all hopes and destructed all grounds for any Austrian-German orientation" (Kuhutyak, 2008: 110). K. Levytskyy was blamed by the Ukrainian politicians in Vienna that he didn't prevent to sign the document; consequently the presidium of the CUC had to resign at the CUC's meeting on November $6^{\text {th }}, 1916$.

On November $8^{\text {th }}, 1916$, due to initiative of the opposition group in the UNDP, the Ukrainian Parliamentary Clubs were dissolved, instead the Ukrainian Parliamentary Representation (UPR) was created, aimed at "presentation of the Ukrainians as integrity inside and outside parliament, struggle against the acts of November $5^{\text {th }}, 17$. It included all Ukrainian ambassadors of the Galicia's sejm and Austrian Parliament headed by Yu. Romanchuk. Regarding the union of parliamentary and sejm ambassadors from Bukovina, being afraid of M. Vasyl'ko's influence, the UPR was categorically against his inclusion.

Having taken initiative, the opposition deputies immediately began to duplicate the structures of the CUC. On November $9-11^{\text {th }}, 1916$, the presidency and parliamentary commission were elected, special commissions were decided to be created at the meetings of the UPR, namely: commission for economic and region restoration (headed by $\mathrm{E}$. Olesnytskyy), commission for the eva-

\footnotetext{
${ }^{16}$ Central State Archive of the highest authorities and administration of Ukraine, File 4, P. 110-111.

Ukrayinske slovo, 1916, November, $28^{\text {th }}$ : 1
}

cuated (headed by E. Petruschevych), the "Fund of national defense" (Расевич, 1999: 327) aimed at reorientation of "the Ukrainian policy only on self-resources and its further transformation into independent from all external factors" 18 .

Being in L'viv, S. Golubovych as a member of the UPR and member of the Regional Credit Union (19151918-s) was mainly involved in the issues of renewal of the ruined Ukrainian lands, governmental assistance to the Ukrainian peasants-emigrants, materials preparation regarding a situation in the region for the Vienna Parliamentary Office, etc. Namely, on November $23^{\text {rd }}, 1916$, he was included into the deputation to the Galicia's governor Diller. The deputation delivered material about the urgent economic problems of the Ukrainian population in the region to the governor. The main demands of the delegates were weekly payment of governmental assistance to the evacuated people at the rate of 1 krona 10 sot, organization of "public procurement based on cesareanimperial bodies or cesarean-imperial regional commands" to the peasants, free clothes and footwear supply, establishment of the constant government of care for the Ukrainian emigrants as a part of cesarean-imperial local government, etc.

Having listened to the representatives, the governor ensured that all necessary measures would be done for emigrants' assistance during three months. Moreover, the delegation discussed the issues of the Ukrainian institutions' participation in cattle and other household animals' turnover, "control implementation in all supporting events of the cesarean-imperial government", etc. ${ }^{19}$

During 1917-1918-s S. Golubovych visited Ternopol and the nearby lands several times, where he met with his electorate, the interests of who he represented in the Austrian government. The main purpose of visiting the city and neighborhood was organization of restoration work, economy renewal. What he had seen and heard in Ternopol he presented in his detailed articles "In the Ternopol's Fire" ${ }^{20}$, "From the Ternopol's Attitudes" ${ }^{21}$ and "From the Ternopol's Bloodbath" ${ }^{22}$. At that time when S. Golubovych was in Ternopol, a conference of the local Ukrainian intelligentsia was held, where it was decided to start immediately the restoration of all Ukrainian organizations in the city as well as it planned to organize a meeting of intelligentsia and all nationally conscious peasants of Ternopol's region and discuss economic, political and organizational issues.

After his return to L'viv S. Golubovych was an active participant of the meetings of the UNDP on November $22^{\text {nd }}$ and December $25-26^{\text {th }}, 1917$, namely concerning the issue that "has shaken all Ukrainian society" regarding the planned union of the Galicia's lands with the new Polish state under the Habsburg's ruler ${ }^{23}$. The loss of hope that Austria-Hungary and Germany would support an aim of the Ukrainians once again convinced the Galicia's politicians in the necessity to join their forces. The meetings were devoted to "the strongest protest declared against the plans of union between the Eastern Galicia... and a planned Polish state in the Austrian and German

\footnotetext{
${ }^{18}$ Ibid, 1916, November $17^{\text {th }}: 2$

19 Ibid, 1918, December, $6^{\text {th. }}: 1$

20 Ibid, 1917, August, $19^{\text {th }}: 1$

21 Ibid, 1917, August, 26 ${ }^{\text {th. }}: 1-2$

$22 \mathrm{Ibid}$ 1917, August, $28^{\text {th }}, 30^{\text {th }}$

${ }^{23}$ Ibid, 1917, November, 24 ${ }^{\text {th }}$ : 1-2
} 
political circles, such forced accession of the Ukrainian lands to Poland was regarded as violence against the whole Ukrainian people with which the Ukrainians would struggle to the death" (Vasylyk, 2004: 50). The following resolutions presented the full support of the Ukrainians of Naddniprianschyna in creation of their governmental body [Svoboda, 1918, January $5^{\text {th: }}: 2$ ], a demand to the Austrian government of necessary presence of the UPR's representatives at the planned peace negotiations in BrestLytovsk was proclaimed, as it would concern an issue of the territories occupied by the Ukrainians within the Habsburg's empire. If the demands ignored once again, the Ukrainians of Galicia would plan to unite with the Ukrainians of Naddniprianschyna ${ }^{24}$.

The members of the UPR and representatives of political parties warmly welcomed proclamation of the Ukrainian National Republic (UNR). There was a way of meetings and demonstrations for the Central Council and policy of M. Gruschevskyy and V. Vynnychenko, etc. in the cities and villages under the guidance of the UPR (Kuhutyak, 2008: 111).

Proclamation of the UNR's independence and peace agreement in Brest-Lytovsk provoked mass celebrations and meeting within Galicia, led to active civic life. The National committee of the UNDP held an extraordinary meeting regarding those events on February $18^{\text {th }}, 1918$; the speakers discussed necessity of the new state's support by the Ukrainians from Galicia and determined March $3^{\text {rd }}$ as a day of Ukrainian statehood ${ }^{25}$.

S. Golubovych was an active participant and coorganizer of the celebration. On March $3^{\text {rd }}$, he visited Ternopol, where 10 thou people - inhabitants of the city and nearby villages gathered for celebration. Traditionally, as in the pre-war period it was open-air liturgy and later a cavalry squad of Sichovi Stril'tsy with the Ukrainian flag rode along the streets. Later according to the program designed by the organizing committee, the commemoration was in the local cinema where S. Golubovych with other famous regional figures - S. Brykovych, P. Karmanskyy, I. Brykovych and V. Vitoschynskyy proclaimed the patriotic speeches. The conversation was about Brest peace treaty, the UNR's creation where the Ukrainians eventually became the owners of their native land, necessity to demand Ukrainian autonomy as a part of Austria. The participants sent a congratulatory message to Kiev and at the end of evening performed "Shche ne vmerla Ukraina" (Hutsal, 1998: 7).

Regarding other places of Ternopil'schyna, several thousands of inhabitants of Gusiatunskyy's district gathered for commemoration in Kopychyntsi that became a center of the district during the war. Approximately 15 thou men gathered to celebrate in Chortkov. The same scale of celebration was in Trebovlia, slightly fewer were in Berezany, Buchach, Zalischyky and other places.

Having worked for the UPR, S. Golubovych was against the coerced practice of the Ukrainian peasants' work for the landowners' fields that was implemented in September 1914; the positive result was reached during the negotiations between the UPR's representatives and the Prime Minister E. Zajdler with the governor of Galicia K. Gujn on April 18-20 ${ }^{\text {th }}, 1918$. Simultaneously, the Austrian government allowed the Ukrainian Union of Galicia's

\footnotetext{
${ }^{24} \mathrm{Ibid}, 1917$, December, $27^{\text {th }}: 2$

${ }^{25}$ Svoboda, 1918, February, $23^{\text {rd }}: 1$

ISSN 1728-9343 (Print)

ISSN 2411-3093 (Online)
}

Cooperatives to purchased 2 million pods of grain in the UNR. The measures had reduced social and multinational tension in the Eastern Galicia. Moreover, the UPR sought permission for the Ukrainian lawyers, architects, engineers, doctors and other certified specialists to occupy administrative and economic positions in the region ( $\mathrm{Ku}$ hutyak, 2008: 113).

The presidency of the UPR with the Metropolitan A. Scheptytskyy had been constantly trying to ratify all conditions of the peace treaty in Brest-Lytovsk during April-July 1918, namely so called "Galicia's protocol" according to which Austria had agreed to prepare draft laws on creation of the Ukrainian imperial land as a part of Austria-Hungary on the territory of Galicia and Bukovina. Nevertheless, all efforts were in vain. The Prime Minister E. Zajdler, loyal to the Ukrainians, was substituted by the chauvinistically-oriented former minister of education Gussarek who unilaterally annulled all secret agreements with the non-existed UNR and made clear concessions to the Polish.

Consequently, the mentioned agreement didn't have any chances to be implemented. A new crisis in the Habsburg's monarchy began that led to its reconstruction (Svoboda, 1918, August, $3^{\text {rd }}$ : 3). The UPR was in opposition to the government of Gussarek. According to its initiative, in August-September 1918 a range of "secret meetings" occurred in L'viv regarding "preparation of administration and army that could occupy L'viv and the Eastern Galicia in the name of Ukrainian statehood".

Simultaneously with the secret preparation of the Ukrainian rebellion, the UPR continued to work under the project of the peace judicial authorities' reelection. It was supposed that a Galicia's governor would be a Ukrainian and after national-territorial autonomy, the time would come to its final separation from Austrian-Hungary (Kuhutyak, 2008: 114).

Therefore, the Galicia's main political parties and UPR strengthened the mass viche movement in the region that went down in history as a "viche week" lasted at the end of September 1918, it should create prerequisites for intensification of the Ukrainian national struggle (Karpenko (ed.), 2001: 134-137). Again S. Golubovych became an active participant and one of the organizers of a "viche week" in Ternopol region (Hutsal, 1999: 54), and participated at the extended meeting of the UPR in L'viv on October $10^{\text {th }}$. The reason of the meeting was the Polish state proclamation in Warsaw on October $8^{\text {th }}$ and on October $9^{\text {th }}$, the Polish acceptance of the ratified decision of the Austrian Parliament regarding accession of all former Polish lands of the Habsburg's monarchy including the Eastern Galicia to the new state. A proposition of E. Levytskyy to convene a national meeting in L'viv on October $18^{\text {th }}$ and create the Ukrainian National Council (UNC) as the only representative body of the Ukrainian nation in Austrian-Hungary was unanimously accepted (Kuhutyak, 2008: 115).

The caesarian manifest proclamation "To my loyal Austrian peoples" on October $16^{\text {th }}$, the UNR creation and its proclamation of Ukrainian state, rapid development of political events and state-building processes in neighboring Poland, Czech Republic and Slovakia had predicted collapse of the Habsburg's empire and beginning of the new era for the Ukrainians in Galicia, the era of statehood creation. 


\section{Conclusions}

Consequently, the main aspects of civic-political activity of S. Golubovych during the World War I were revealed as a result of the study. It was mentioned that the activity was predominantly oriented on the struggle for autonomy of Galicia and against its accession to the renewed Polish state. Being a member of the Ukrainian Parliamentary Club in Vienna and member of the UNDP, he was for the union of all national-political forces in emigration into a common Ukrainian organization, as a constant opposition between different party groups in the political circles of Galicia and Bukovina had reduced significance of the Ukrainian issue in the light of being a crucial factor of European policy.

As a member of the CUC and later the UPR, S. Golubovych protected the interests of the Ukrainian internees in the camps in Austria, Germany and Czech Republic, refugees, was involved in the political actions for autonomy of Ukrainian schooling, Ukrainian university opening, transformation of the STC into the Ukrainian academy of science, etc. After his return to L'viv in August 1915, S. Golubovych as a member of the L'viv's delegation of the CUC and member of the Regional Credit Union was predominantly responsible for the problems of region's restoration after the military actions. Simultaneously, the main attention was drawn to the active social activity, namely he was included into the senior council at Stavropigijskyi institute and was an editor of the newspaper "Ukrayins'ke slovo" that was the main media source in Galicia.

Before the November events of 1918 , the future figure of the WUNR participated in organization of meetings and demonstrations devoted to the independence proclamation of the UNR, peace treaty agreement in Brest-Lytovsk, was actively involved in implementation of so called "viche week" organized to support the autonomy demands of the Eastern Galicia as a separate Ukrainian territory within the Austrian state, etc. Under the circumstances of post-war destruction such activity supported national-political struggle among Galicia's population for the sake of reaching the main goal - realization of statehood.

\section{REFERENCES}

Hlovatskyy, I (2008). Ukrayinski advokaty Skhidnoyi Halychyny v svitli arkhivnykh dzherel. 1800-1939 rr. (in Ukrainian)

Hutsal, P. Z. (1998). Svyato ukrayinskoyi derzhavnosti na Ternopilli. Do 80-richchya nezalezhnosti UNR. Osvityanyn, 2: 7 (in Ukrainian)

\section{Оксана Камінска,}

Інститут гуманітарних і соиіальних наук,

Національний університет «Львівська політехніка» (м. Львів, Украӥна)

e-mail: oksanakaminska11@gmail.com,ORCID 0000-0003-2695-2440

\section{УЧАСТЬ СИДОРА ГОЛУБОВИЧА У СУСПІЛЬНО-ПОЛІТИЧНИХ ПРОЦЕСАХ НА ГАЛИЦЬКИХ ЗЕМЛЯХ ПІД ЧАС ПЕРШОї СВІТОВОЇ ВІЙНИ}

У статті на основі комплексного вивчення архівних джерел, періодичної преси та наукової літератури проаналізовано громадсько-політичну діяльність Сидора Голубовича в роки Першої світової війни. 3'ясовано його роль у діяльності політичних організацій у Відні в умовах еміграції 1914-1915 рр. та після повернення його до Львова у 1915-1918 рр. Зокрема, показано передумови до реорганізації Головної Української Ради у Загальну Українську Раду, висвітлено проблему політичної боротьби між окремими партійними групами в галицько-буковинському політикумі. Розкрито також головні аспекти діяльності
ISSN 1728-9343 (Print) ISSN 2411-3093 (Online) 
С. Голубовича у Загальній Українській Раді (ЗУР), де головну увагу приділено проблемам створення «Воєнного банку», питань українських біженців, сезонних робітників та інтернованих українців з Галичини та Буковини, яких за офіційними даними налічувалося понад 90 тисяч у різних місцевостях Австрії, Німеччини та Чехії. Також, зазначено, що С. Голубович був учасником політичних акцій за автономність українського шкільництва, відкриття окремого українського університету у Львові, перетворення НТШ на українську академію наук тощо.

3'ясовано, що після повернення у серпні 1915 р. до Львова, С. Голубович як член львівської делегації ЗУР та член дирекції Крайового Союзу Кредитового (КСК) займався, головним чином, вирішенням проблем відбудови зруйнованого військовими діями краю. Водночас, значну увагу приділяв і активній громадській діяльності, зокрема став членом ради старшини Ставропігійського Інституту - колишньої москвоффільської інституції, яку австрійський намісник генерал Коллард передав українцям та був засновником і редактором газети «Українське слово», що стала провідним часописом Галичини. Окрім цього, політик у 1917-1918 рр. неодноразово відвідував Тернопільський повіт, де намагався підтримувати тісний зв'язок зі своїми виборцями.

Показано роль С. Голубовича напередодні листопадових подій 1918 р., де він як член Української національно-демократичної партії (УНДП) та член Української парламентарної репрезентації (УПР) брав участь в організації мітингів та демонстрацій на честь проголошення незалежності Української Народної Республіки (УНР), підписання мирного договору у Брест-Литовську, був учасником проведення т. зв. «вічового тижня» на підтримку вимог автономії Східної Галичини як окремої української території в рамках Габсбурзької монархії тощо.

Ключові слова: С. Голубович, Український парламентський клуб, Українська національно-демократична партія (ліве опозиційне крило), Загальна Українська Рада, Українська парламентарна репрезентація, газета «Українське слово».

(c) Oksana Kaminska

Надійшла до редакції: 02.11.2021

Прийнята до друку: 26.11.2021 